\title{
The effect of processing methods on the functional and compositional properties of jackfruit seed flour
}

\author{
Eke- Ejiofor, J., Beleya, E. A., Onyenorah, N. I. \\ Department of Food Science and Technology, Rivers State University of Science and Technology, Nkpolu, P.M.B. 5080, Port Harcourt \\ Email address: \\ joyekee@yahoo.co.uk (Eke- Ejiofor, J.)
}

To cite this article:

Eke- Ejiofor, J., Beleya, E. A., Onyenorah, N. I.. The Effect of Processing Methods on the Functional and Compositional Properties of Jackfruit Seed Flour. International Journal of Nutrition and Food Sciences. Vol. 3, No. 3, 2014, pp. 166-173.

doi: $10.11648 /$ j.ijnfs.20140303.15

\begin{abstract}
The effects of processing on the functional, chemical and pasting properties of jackfruit seed flour were investigated. The values for dispersibility ranged from $75.75 \%$ to $85.75 \%$ with GJFSF (germinated jackfruit seed flour) being significantly different $(\mathrm{p} \leq 0.05)$ from the dried (control), autoclaved, boiled and roasted jackfruit seed flour samples. Oil absorption for the samples ranged from $150 \%$ to $300 \%$ with AJFSF (autoclaved jackfruit seed flour) and GJFSF being significantly different $(\mathrm{p} \leq 0.05)$ from the dried (control), boiled and roasted jackfruit seed flour samples. Swelling power ranged from $6.58 \%$ to $9.46 \%$ with Control (dried jackfruit seed flour) and GJFSF being significantly different ( $\mathrm{p} \leq 0.05)$ from the autoclaved, boiled and roasted samples. Bulk density values ranged from $0.256 \mathrm{~g} / \mathrm{ml}$ to $0.327 \mathrm{~g} / \mathrm{ml}$ with GJFSF being significantly different $(\mathrm{p} \leq 0.05)$ from control, AJFSF, BJFSF and RJFSF samples. The color of the flour samples ranged from $74.76 \%$ to $82.59 \%$ with Control being significantly different $(\mathrm{p} \leq 0.05)$ from the autoclaved, boiled germinated and roasted jackfruit seed flour samples. Water absorption capacity, solubility, least gelation concentration, moisture, crude fiber, ash and carbohydrates showed no significant differences ( $\mathrm{p} \geq 0.05$ ) in all the samples. Protein content ranged from $12.25 \%$ to $16.80 \%$ with RJFSF (roasted jackfruit seed flour) being significantly different $(\mathrm{p} \leq 0.05 \%)$ from the dried (control), autoclaved, boiled and germinated jackfruit seed flour samples. The crude fat ranged from $0.13 \%-0.77 \%$ with dried (control), AJFSF and BJFSF (autoclaved and boiled jackfruit seed flour) being significantly different $(\mathrm{p} \leq 0.05)$ from the germinated and roasted samples. The starch content ranged from $26.55 \%$ to $36.03 \%$ with AJFSF being significantly different $(p \leq 0.05)$ from the dried, boiled germinated and roasted jackfruit seed flour samples. Sugar content ranged from $0.50 \%$ to $2.48 \%$ with RJFSF being significantly different $(\mathrm{p} \leq 0.05)$ from the dried (control), autoclaved boiled and germinated samples. Amylose and amylopectin contents ranged from $15.72 \%$ to $23.79 \%$ and $76.21 \%$ to $84.28 \%$ with GJFSF and AJFSF being significantly different ( $\mathrm{p} \leq 0.05$ ) from BJFSF and RJFSF samples. The peak viscosity for the samples ranged from 743.50RVU to 4260RVU with RJFS being significantly different $(\mathrm{p} \leq 0.05)$ from the control, AJFSF, BJFSF and GJFSF samples. Trough, breakdown, and final viscosity showed no significant difference ( $\mathrm{p} \geq 0.05$ ), while Setback viscosity ranged from 395.50RVU -1388RVU with Control and RJFS being significantly different $(\mathrm{p} \leq 0.05)$ for AJFSF, BJFSF and GJFSF samples. While the maximum pasting time and temperature was reached at $8.46 \mathrm{mins}$ and $93.9^{\circ} \mathrm{C}$ respectively.
\end{abstract}

Keywords: Processing Methods, Functional, Compositional, Properties, Jackfruits

\section{Introduction}

Jackfruit (Artocarpus heterophyllus) belongs to the family moraceae, (Mulberry family). It is native to India and is also found in many parts of South East Asia. It is also cultivated in the evergreen forest zone of West Africa (1) (Burkill, 1997). Its fruit is one of the largest among edible fruits.

In Nigeria, it is not very common because cultivation has not been encouraged, though it is found in the South coastal parts of the country, where it grows wild or semi conserved.
Jackfruit consist about $29 \%$ pulp, $12 \%$ seeds and $54 \%$ rind (2) Berry and Kalra, (1988). It provides about $2 \mathrm{MJ}$ of energy per kg-wet weight of ripe perianth (3) (Ahmed et al, 1986). Jackfruit has been reported to contain high levels of protein, starch, calcium and thiamine (1) Burkill, 1997). It is also rich in energy, dietary fiber, minerals and vitamin. Nevertheless, it contains no saturated fats or cholesterol making it a healthy fruit to savor.

The interior of the ripe fruit consists of large, pleasant flavored, sweet yellow bulb, massed among narrow ribbons 
of thin, though underdeveloped, and a central pity core which consists $25-30 \%$ of the total fruit.

(4) Goswani et al (2010), reported the following for raw jackfruit seed, $4.27 \%$ ash, $6.73 \%$ protein, $73.34 \%$ starch, $0.80 \%$ fat and $1.6 \%$ fiber. Additionally, Odoemelam (2005) reported the following functional properties of jackfruit seed flour as, $(16 \%) \mathrm{W} / \mathrm{V}$ least gelation concentration, $230 \%$ water absorption capacity (WAC), 280\% Oil absorption capacity (OAC) and $0.6 \mathrm{~g} / \mathrm{ml}$ bulk density.

The seeds are used in several culinary operations. They are eaten after boiling or roasting or are dried and salted as table nuts. They can also be ground to make flour, which is blended with wheat flour for baking. Due to its high carbohydrate content and other nutrients, they can be added to baked products for value addition without affecting the functional and sensory properties of the final product. Moreover, incorporation of seed flour to deep fat fried products has been found to reduce fat absorption to a remarkable extent (5) (Rajarajeshwari and Jamuma, 1999).
The objective of this study therefore is to determine the effects of processing methods on the functional, chemical and pasting properties of jackfruit seed flour.

\section{Material and Methods}

Whole jackfruits where purchased from Oru East Local Government area of Imo State, Nigeria.

\subsection{Chemicals}

Chemicals used were obtained from Food Science and Technology laboratory, Rivers State University of Science and Technology (RSUST) and were all of analytical grade.

\subsection{Methods for Jackfruit Seed Flour Production}

Different processing methods were used to process the jackfruit seeds into flour as shown in figure 1 below.

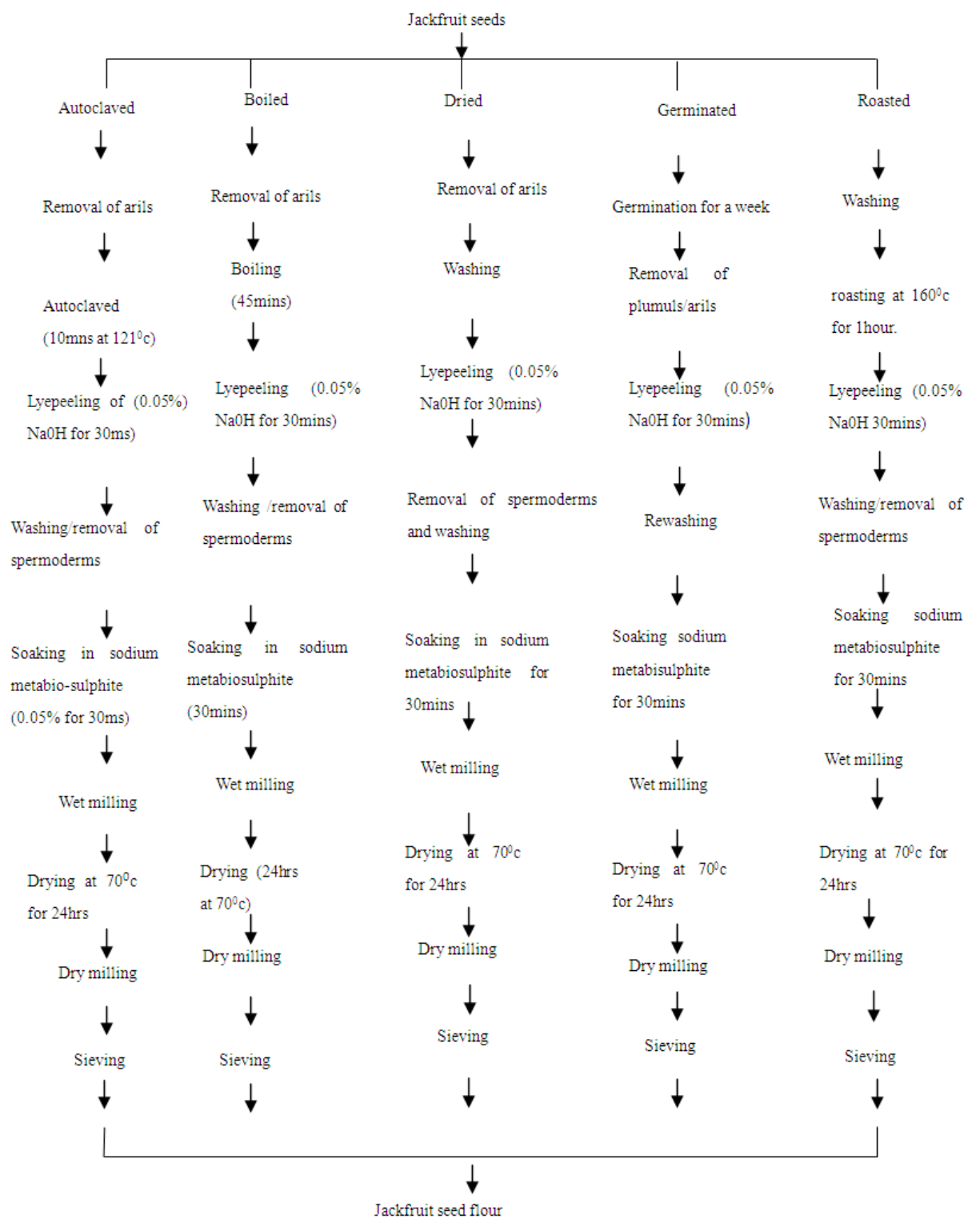

Fig 1. Production of Jackfruit seed flour 


\subsubsection{Functional Properties of Processed Jackfruit Seed Flour}

Dispersibility was determined by the method described by (6) Kulkani et al., (1991). Swelling power and solubility was determined by the method described by (7) Takashi and Sieb (1988). Water/Oil absorption capacity (WAC) was determined by the method described by (8) Sosulski (1962). Bulk density was determined by the method of (9) Naragana and Narasinga Rao (1984). While least gelation concentration and color indices were determined by the method of (10) Coffman and Garcia. (1977) and (11) Francis (1998) respectively.

\subsubsection{Chemical Analysis of Jackfruit Seed Flour}

Moisture, ash, crude protein and fats were determined by the (12) AOAC (1984) method. Crude fiber was estimated by the method of (13) Mayanard (1970. The carbohydrate content was calculated by difference, (100- sum of the values for moisture, crude protein, crude fiber, crude fat and crude ash). (14) (Raghuramulu et al.,1983). Starch and Sugar were determined by the method described by (15) Dubois et al., (1956) as described in (16) Eke-Ejiofor and Kiin Kabari, 2010. Amylose content was determined by the method described by (17) Williams et al., (1970).

\subsubsection{Determination of Pasting Properties}

Pasting properties were determined with a Rapid Visco Analyzer (RVA, model 3C, Newport Scientific PTY Ltd, Sydney).

\subsection{Statistical Analysis}

All data obtained from various analysis were pooled and subjected to analysis of variance (ANOVA) using the statistical package for social sciences (SPSS) version 15.0. Means were separated using New Duncan's Multiple Range Tests (18) (Duncan, 1955) at 95\% confidence level ( $\mathrm{p} \leq 0.05)$.

\section{Results and Discussion}

\subsection{Functional Properties of the Jackfruit Seed Flour Samples}

Table 1 shows the functional properties of Jackfruit seed flour. Dispersibility ranged from $75.75 \% \quad 85.75 \%$ with sample AJFSF having the least and control the highest value. Dispersibility determines the tendency of flour to move apart from water molecules and reveals its hydrophobic action. (6) Kulkani et al., (1991) reported that the higher the dispersibility, the better the starch reconstitutes in water to give a fine and consistent paste.

Water and Oil absorption capacities ranged from 400\% to $600 \%$ and $150 \%$ to $300 \%$ respectively. Water absorption capacity ranging from $4.0 \mathrm{~g} / \mathrm{ml}$ to $6.0 \mathrm{~g} / \mathrm{ml}$ with Control having the lowest and RJFSF having the highest value, were higher than that reported by (19) Odoemelam, (2005) of $2.3 \mathrm{~g} / \mathrm{ml}$, (5) Rajarajeshwari and Jamuma; (1999), of $2.1 \mathrm{~g} / \mathrm{ml}$ and (20) Tulyathan et al., (2002), of $2.05 \mathrm{~g} / \mathrm{ml}$. (21)
Niba et al., (2001) described water absorption capacity as an important processing parameter that has implications for viscosity. Furthermore, water absorption capacity is important in bulking and consistency of products as well as baking applications. Similarly, the reverse was the case for oil absorption capacity. The oil absorption capacity obtained for the seed flour samples in this study ranged from $1.5 \mathrm{~g} / \mathrm{ml}$ to $3.0 \mathrm{~g} / \mathrm{ml}$ with RJFSF having the lowest value and Control having the highest. This was slightly higher than that obtained by (19) Odoemelam, (2005) with a value of $2.8 \mathrm{~g} / \mathrm{ml}$, while (5) Rajarajeshwari and Jamuma, (1999), reported a value of $1.8 \mathrm{~g} / \mathrm{ml}$ for jackfruit seed flour. However, Singh et al; (1991) reported a value of $0.90 \mathrm{~g} / \mathrm{ml}$ and (20) Tulyathan et al., (2002) reported a value of $0.92 \mathrm{~g} / \mathrm{ml}$ for whole jackfruit seeds without brown spermoderms. Oil absorption is an important property in food product development because it impacts flavor and mouth feel to foods .There were significant differences $(\mathrm{P} \leq 0.05)$ in the samples for each method used

Swelling power and solubility ranged from $6.58 \%$ to $9.46 \%$ and $8.35 \%$ to $14.47 \%$ with RJFS having the least value and GJFSF having the highest value in both cases respectively.

Swelling power of the seed flour samples ranging from $6.58 \%$ to $9.46 \%$ is lower than that reported by (22) Ocloo et al, (2010), who gave a value of $4.77 \%$. However the values obtained in this study is close to the range reported (23) by Daramola and Osanyinlusi, (2006) for native and ginger modified starches respectively. Swelling power is a measure of swollen starch granule, food eating quality is connected with retention of water swollen starch granules. (24) (Rickard et al., 1992). There were significant differences $(\mathrm{P} \leq 0.05)$ in the samples for each method used.

The values obtained for solubility of the seed flour samples ranged from $8.24 \%$ to $14.48 \%$ with RJFSF having the lowest and GJFSF having the highest. Solubility reflects the extent of intermolecular cross bonding with the granule (25) (Hari et al., 1989). There was no significant difference $(\mathrm{P} \geq 0.05)$ in the samples.

The least gelation concentration for all the samples occurred at $12 \%$. Least gelation concentration can be described as a measure of the minimum amount of starch/flour or their blends that is needed to form gel in a given volume of water. The higher the least gelation concentration, the higher the starch/flour needed to form gel (26) (Adebowale, 2002). The concentration at which all flour samples gelled was determined to be $12 \%(\mathrm{w} / \mathrm{v})$. This value was exactly the same with that reported by (19) (Odoemelam,(2005) for heat processed (12\%) African breadfruit flour. This is lower than that reported for raw and processed jackfruit seed flour which were determined to be $16 \%$ and $18 \%$ respectively (27) (Chowdbury et al 2012). The variations in the gelling properties of the flour samples may be due to the different treatments given to the samples which are likely to bring about variation in different constituents such as carbohydrates, proteins and lipids. The 
gelling capacity of flour has been attributed to denaturation, aggregation and thermal degradation of starch (28) (Enwere and Ngoddy, 1986). Result of least gelation concentration shows that jackfruit seed flour is a good gelling agent and may be useful in food systems such as puddings (19) (Odoemelam, 2005). There was no significant difference $(\mathrm{P} \geq 0.05)$ in the samples.

Bulk density values ranged from $0.256 \mathrm{~g} / \mathrm{ml}$ to $0.327 \mathrm{~g} / \mathrm{ml}$ with RJFSF having the least and GJFSF having the highest value. Bulk density for the samples ranged from $0.26 \mathrm{~g} / \mathrm{ml}$ to $0.33 \mathrm{~g} / \mathrm{ml}$ with RJFSF having the lowest and GJFSF having the highest. This was lower than the values reported by (19) Odoemelam, (2005) for heat processed $(0.54 \mathrm{~g} / \mathrm{ml})$ and raw $(0.61 \mathrm{~g} / \mathrm{ml})$ jack fruit seed flour. Heat processing reduced the bulk density of jackfruit seed flour by $11.5 \%$ (19) (Odoemelam,2005). Bulk density is a measure of the heaviness of a flour sample. It is important for determining packaging requirements, material handling and application in wet processing in the food industry (22) (Ocloo et al., 2010).

Table 1. Functional properties of jackfruit seed flour samples

\begin{tabular}{|c|c|c|c|c|c|c|c|c|}
\hline Sample & Dispersibility (\%) & WAC (\%) & OAC (\%) & Solubility (\%) & $\begin{array}{l}\text { Swelling power } \\
(\%)\end{array}$ & LGC (\%) & Bulk den. g/m-1 & Color (\%) \\
\hline Control & $80.50 \pm 0.60^{b}$ & $450 \pm 70.71^{a}$ & $300 \pm 0.00^{\mathrm{a}}$ & $13.20 \pm 0.98^{\mathrm{a}}$ & $8.41 \pm 0.33^{\mathrm{a}}$ & $12.00 \pm 0.00^{\mathrm{a}}$ & $0.298 \pm 0.00^{\mathrm{d}}$ & $82.59 \pm 0.21^{\mathrm{a}}$ \\
\hline AJFSF & $75.75 \pm 0.35^{\mathrm{c}}$ & $400 \pm 0.00^{\mathrm{a}}$ & $200 \pm 0.00^{b}$ & $9.72 \pm 5.39^{\mathrm{a}}$ & $6.58 \pm 0.57^{b}$ & $12.00 \pm 0.00^{\mathrm{a}}$ & $0.304 \pm 0.00^{\mathrm{c}}$ & $77.55 \pm 0.14^{b}$ \\
\hline BJFSF & $76.75 \pm 0.35^{\mathrm{c}}$ & $500 \pm 0.00_{\mathrm{a}}$ & $200 \pm 0.00^{b}$ & $14.36 \pm 1.67^{\mathrm{a}}$ & $6.69 \pm 0.40^{\mathrm{b}}$ & $12.00 \pm 0.00^{\mathrm{a}}$ & $0.323 \pm 0.00^{\mathrm{b}}$ & $76.61 \pm 1.06^{b}$ \\
\hline GJFSF & $85.75 \pm 1.06^{\mathrm{a}}$ & $550 \pm 21.13^{\mathrm{a}}$ & $300 \pm 0.00^{\mathrm{a}}$ & $14.47 \pm 0.91^{\mathrm{a}}$ & $9.46 \pm 0.59^{a}$ & $12.00 \pm 0.00^{\mathrm{a}}$ & $0.327 \pm 0.00^{\mathrm{a}}$ & $82.47 \pm 0.23^{\mathrm{a}}$ \\
\hline RJFSF & $78.75 \pm 0.70^{c}$ & $600 \pm 0.00 .^{\mathrm{a}}$ & $150 \pm 70.71^{b}$ & $8.35 \pm 5.65^{\mathrm{a}}$ & $6.84 \pm 0.56^{\mathrm{b}}$ & $12.00 \pm 0.00^{\mathrm{a}}$ & $0.256 \pm 0.00^{\mathrm{e}}$ & $74.76 \pm 0.01^{\mathrm{c}}$ \\
\hline
\end{tabular}

Values with the same superscripts in the same column are not significantly different $(\mathrm{p} \geq 0.05)$.

Key:

Control - Dried jackfruit seed flour

AJFSF - Autoclaved jackfruit seed flour

BJFSF - boiled jackfruit seed flour

GJFSF - Germinated jackfruit seed flour

RJFSF - Roasted jackfruit seed flour

WAC - Water absorption capacity

OAC - Oil absorption capacity

LGC - Least gelation concentration

The color analysis for the various samples ranged from $74.76 \%$ to $82.59 \%$ with RJFSF having the lowest and Control having the highest. The color intensity of the flours ranging from $74.76 \%-82.59 \%$ for RJFSF and Control indicates whiteness. Flour extracted under perfect condition is pure white in color and it is an important criterion for flour quality. There were significant differences $(\mathrm{P} \leq 0.05)$ in the samples for each method used. Color values of $90.15 \%$ and $89.40 \%$ have been reported by (29) Amornrat and Karmontip (2004) for wet and dry milled jackfruit seed flour respectively.

\subsection{Chemical Composition of the Seed Flour Sample}

Table 2 shows moisture content of the flour samples which ranged from $3.20 \%$ to $6.6 \%$ with GJFSF having the lowest and BJFSF having the highest value. This was slightly higher than that reported by (22) Ocloo et al., (2010) of 6.09\%. (29) Amornrat and Karmontip (2004) also reported a value of $8.57 \%$ and $6.34 \%$ respectively for wet and dry milled jackfruit seed flour. Moisture provides a measure of the water content of the seed flour samples and its total solid content. It is also an index of storability of the flour. Reduced moisture content implies better shelf life and stability. Moisture content showed no significant difference $(\mathrm{P} \leq 0.05)$ in the samples.

Ash content of the flour samples ranged from $2.45 \%$ to $2.76 \%$ with RJFS having the lowest and GJFSF having the highest.

Ash content of $2.76-3.31 \%$ have been reported for jackfruit seed (30) (Morton, 1987) (20) Tulyathan et al.,
(2002) reported a value of $3.92 \%$ whereas (5) Rajarajeshwari and Jamuma (1999) reported a value of $2.00 \%$ and (31) Kumar et al., (1988) recorded a value $1.27 \%$ which are lower than the values obtained in the present study. There were no significant differences $(\mathrm{P} \geq 0.05)$ in the samples. Ash is the organic residue remaining after the organic matter has been burnt away (22) (Ocloo et al., 2010).

Protein content of the flour samples ranged from 12.25 to $16.80 \%$ with AJFSF having the lowest and RJFSF having the highest values. (22) Ocloo et al., (2010) reported a protein value of $13.50 \%$ for jackfruit seed flour sample. BJFS had a value (13.48\%) which was slightly lower. (31) Kumar et al., (1988) also reported a protein content range of $17.8-18.3 \%$ for jackfruit seed flour. This was higher than that obtained in the present study. Lower values 6.34 $8.57 \%$ have also been reported for jackfruit seed flour (29) (Amornrat and Kamontip, 2004). (5) Rajarajeshwari and Jamuma, (1999) reported a value of $21.30 \%$ protein in jackfruit seed flour. (32) Bobbio et al., (1978) also reported an extraordinary value of $31.9 \%$. The protein content in the present study indicates that jackfruit seed flour can help reduce the incidences of protein energy malnutrition, if used in composite with less protein rich flour. There were significant differences $(\mathrm{P} \leq 0.05)$ in the samples for each method used.

Fat content of the flour samples ranged between $0.13 \%$ to $0.77 \%$ with GJFS having the lowest and Control having the highest value. (31) Kumar et al.,(1988) reported a fat content of $0.78 \%$ for jackfruit seed flour, which was in 
range with the Control sample. (22) Ocloo et al., (2010) reported a higher fat content value of $1.27 \%$, (30) Morton (1987) reported a fat content of $0.88 \%$. (33) Singh et al., (1991) reported a fat content of $2.2 \%$ for jackfruit seed flour. There were significant differences $(\mathrm{P} \leq 0.05)$ in the samples for each method used. These values are relatively low when compared to pearl millet $(7.6 \%)$ and quinoa (6.3\%) (34) (Oshodi et al., 1999), pigeon pea flour (1.80\%) (35) (Okpala and Mammah, 2001), and wheat flour 3.10\% (36) (Akubor and Badifu, 2004).

Carbohydrate values obtained from this study ranged from $70.76 \%$ to $79.04 \%$ with Control having the lowest and GJFSF having the highest. This result is comparable to that obtained by (33) Singh et al., (1999) who reported 74\%, Ocloo et al., (2010) reported 79\%, (31) Kumar et al., (1988) reported $76.1 \%$ and (21) Tulyathan et al., (2002) reported a carbohydrate content of $81.64 \%$. However, the value obtained was lower than $66.2 \%$ reported by (32) Bobbio et al.,( 1978). (37) Siti and Noor, (2003) also reported a carbohydrate content of $75.71 \%$. There was no significant difference $(\mathrm{P} \geq 0.05)$ in the samples.

Sugar content of the samples ranged from $0.50 \%$ to $2.48 \%$ with AJFSF having the lowest and RJFSF having the highest. There were significant differences $(\mathrm{P} \leq 0.05)$ in the samples for each method used.

Crude fiber content of the flour samples ranged between $2.43 \%$ to $6.17 \%$ with Control having the lowest value and AJFSF having the highest. A lower value of $2.36 \%$ was reported by (19) Tulyanthan et al., (2002). Rajarajeshwari and Jamuma (1990) reported a value of $5.69 \%$ which was in range with the values obtained in the present study. There were no significant differences
$(\mathrm{P} \geq 0.05)$ in all samples. The starch content of the seed flour samples ranged between 26.55-36.03\% with Control having the lowest and AJFSF having the highest content. There were significant differences $(\mathrm{P} \leq 0.05)$ in the samples for each method used.

Amylose and amylopectin content for the various flour samples ranged from $15.72 \%$ to $23.79 \%$ and $76.21 \%$ to $84.28 \%$ with AJFSF and GJFSF having the lowest values and GJFSF and AJFSF having the highest values respectively.. Roasting is one of the traditional methods of processing jackfruit seeds for consumption. The Amylose content of the flour samples ranged between $15.72 \%$ to $23.79 \%$ with AJFSF having the lowest and GJFSF having the highest values. The differences in amylose content may be as a result of the different heat treatments on the various samples. In agreement with the above statement, (38) Raja and Ramakrishna (1990) reported that heat treatment causes a reduction in the amylose content of cassava based products. The amylose content of the raw material is an important factor with regard to end use properties of the product. (39) (Sievert and Lausanne, 1993). There were significant differences $(\mathrm{P} \leq 0.05)$ in the samples for each method used.

Amylopectin content of the flour samples ranged from $76.21 \%$ to $84.28 \%$ with GJFSF having the lowest and AJFSF having the highest. This shows that amylopectin increased with a decrease in amylose, meaning that one is a function of the other and both properties are important in food preparation and development. Amylopectin contributes to high viscosity and waxiness in starch (16) (Eke-Ejiofor and Kin-Kabari, 2010).

Table 2. Chemical properties of jackfruit seed flour(\%).

\begin{tabular}{|c|c|c|c|c|c|c|c|c|}
\hline Sal & sh & & at & & & & & \\
\hline $15.07 \pm 0.47^{\mathrm{a}}$ & $2.46 \pm$ & & $77 \pm 0.85^{\mathrm{a}}$ & & 70.7 & $26.55 \pm 0$. & $00 \pm 0.0500$ & \\
\hline F $6.58=$ & $2.59 \pm 0.00^{\mathrm{a}}$ & $12.25 \pm 0.00^{\mathrm{b}}$ & $0.68 \pm 0.28^{\mathrm{a}}$ & & $71.73 \pm$ & $36.03 \pm 0$. & & \\
\hline F 6.60 & $2.56 \pm 0.00^{\mathrm{a}}$ & & & & $72.05 \pm$ & $27.10 \pm 3.5$ & & \\
\hline F 3.2 & 2.76 & & 0.1 & & 79.0 & & & \\
\hline RJFSF $4.44 \pm 3.50^{\mathrm{a}}$ & $2.45 \pm 0.00^{\mathrm{a}}$ & $16.80 \pm 2.23^{\mathrm{a}}$ & & $3.38 \pm 2.69^{\mathrm{a}}$ & $72.16 \pm 3.21^{\mathrm{a}}$ & $30.71 \pm 0.4$ & ${ }^{\mathrm{c}} 2.48 \pm 0.04^{\mathrm{a}} 79.85$ & $20.15 \pm 0.2^{\mathrm{b}}$ \\
\hline
\end{tabular}

Values with the same superscripts in the same column are not significantly different $(\mathrm{p} \geq 0.05)$.

Key:

Control - Dried jackfruit seed flour.

AJFSF - Autoclaved jackfruit seed flour

BJFSF - Boiled jackfruit seed flour

GJFSF - Germinated jackfruit seed flour

RJFSF - Roasted jackfruit seed flour

\subsection{Pasting Properties of the Seed Flour Samples}

An investigation on the pasting characteristics of the seed flour samples revealed differences which may be attributed to the processing methods used. Table 3 shows the peak viscosity during heating, this ranged from 743.5RVU to 4260.5RVU with AJFSF having the lowest and RJFS having the highest. Peak viscosity is indicative of the strength of the pastes which are formed from gelatinization during processing in food applications and higher peak viscosity corresponds to a higher thickening power of the starch. (40) (Swinkles, 1985).

The trough value ranged between 696 RVU to 3126RVU with AJFSF having the lowest and RJFSF having the highest. The break down viscosity followed the same trend, with AJFSF having the lowest breakdown valued with 47.5RVU and RJFSF having the highest value with 1338RVU. (41) Moorthy et al., (1996) was of the opinion that cohesiveness of starch was attributed to the breakdown viscosities of starch molecules during heating and stirring. Final viscosity ranged from 1091.5RVU to 3618.5 RVU 
with AJFSF having the lowest and RJFSF having the highest. This determines the ability of a material to form gel during processing, (16) (Eke-Ejiofor and Kin-Kabari, 2010). (29)Armonrat and Kamontip (2004), reported a final viscosity value of 58.16RVU and 32.76RVU for wet and dry milled jackfruit seed flour respectively. This is lower than the values obtained from the present study.

Setback ranged from 395.5RVU to 1388RVU with AJFSF having the lowest and RJFSF having the highest. Setback viscosity indicates gel stability and potential for retrogradation. (29) Armonrat and Kamontip (2004) reported setback values of 18.53RVU and 10.56RVU for wet and dry milled jackfruit seed flour

Peak time for the flour samples ranged from $3.5 \mathrm{mins}$ to 8.46mins with AJFSF having the lowest and GJFS having the highest gelling time. (29) Armonrat and Kamontip (2004), reported peak time values of 8.70 minutes and 8.65minutes for wet and dry milled jackfruit seed flour samples. This was slightly higher than that obtained in the present study. Pasting temperature of the seed flour samples ranged from $88.5^{\circ} \mathrm{C}$ to $93.9^{\circ} \mathrm{C}$ with Control having the lowest temperature and GJFSF having the highest temperature value.

A pasting temperature of $88.2^{0} \mathrm{c}$ was also recorded by (22) Ocloo et al., (2010) for jackfruit seed flour, which was higher than that reported by (20) Tulyanthan et al., (2002) for jackfruit starch. (32) Bobbio et al., (1978), also reported an initial pasting temperature of $74.5^{\circ} \mathrm{c}$ for jackfruit seed starch and also stated that the seed starch granules were not susceptible to break down either by thermal or mechanical shear. This disparity between starch and flour is expected since jackfruit seed flour is not a pure sample as compared with jackfruit seed starch. Also it was observed that heat processed flour had slight variations in pasting temperature. These differences obtained in all analysis done on the flour samples may be as a result of the processing methods used.

Table 3. Pasting characteristics of jackfruit seed flour

\begin{tabular}{|c|c|c|c|c|c|c|c|}
\hline Sample & $\begin{array}{l}\text { Peak viscosity } \\
\text { (RVU) }\end{array}$ & Trough 1 (RVU) & $\begin{array}{l}\text { Break down } \\
\text { viscosity }(R V U)\end{array}$ & $\begin{array}{l}\text { Final viscosity } \\
\text { (RVU) }\end{array}$ & $\begin{array}{l}\text { Set back viscosity } \\
\text { (RVU) }\end{array}$ & $\begin{array}{l}\text { Pasting time } \\
\text { (mins) }\end{array}$ & Pasting temp $\left({ }^{\circ} \mathrm{C}\right)$ \\
\hline Control & $3209.0 \pm 151.32^{b}$ & $2026.50 \pm 50.20^{b}$ & $1182.50 \pm 19.12^{b}$ & $3249.50 \pm 212.84^{b}$ & $1223.0 \pm 162.63^{\mathrm{a}}$ & $5.29 \pm 0.23^{\mathrm{c}}$ & $88.50 \pm 0.56^{\mathrm{c}}$ \\
\hline AJFSF & $743.5 \pm 27.57^{d}$ & $696.00 \pm 24.04^{\mathrm{d}}$ & $47.50 \pm 3.54^{\mathrm{c}}$ & $1091.50 \pm 16.26^{\mathrm{c}}$ & $395.5 \pm 7.78^{b}$ & $7.00 \pm 0.00^{\mathrm{b}}$ & $92.45 \pm 0.56^{\mathrm{ab}}$ \\
\hline BJFSF & $1039 \pm 178.19^{c}$ & $983 . \pm 175.36^{\mathrm{c}}$ & $56.00 \pm 2.83^{c}$ & $1380.00 \pm 200.82^{c}$ & $387.0 \pm 25.46^{b}$ & $6.73 \pm 0.28^{b}$ & $90.82 \pm 1.66^{\mathrm{b}}$ \\
\hline GJFSF & $855.50 \pm 16.26^{\mathrm{cd}}$ & $800.50 \pm 16.26^{\mathrm{cd}}$ & $62.50 \pm 3.53^{c}$ & $1220.50 \pm 17.68^{c}$ & $504.5 \pm 9.19^{b}$ & $8.46 \pm 0.00^{\mathrm{a}}$ & $93.90 \pm 0.07^{\mathrm{a}}$ \\
\hline RJFSF & $4260.50 \pm 72.83^{a}$ & $3126.5 \pm 38.89^{a}$ & $1338 \pm 57.98^{\mathrm{a}}$ & $3620 \pm 89.11^{\mathrm{a}}$ & $1388 \pm 128.69^{a}$ & $5.65 \pm 0.01^{\mathrm{c}}$ & $91.00 \pm 0.07^{\mathrm{b}}$ \\
\hline
\end{tabular}

Values with the same superscripts in the same column are not significantly different $(\mathrm{p} \geq 0.05)$.

Key:

Control - Dried jackfruit seed flour

AJFSF - Autoclaved jackfruit seed flour

BJFSF - Boiled jackfruit seed flour

GJFSF - Germinated jackfruit seed flour

RJFSF - Roasted jackfruit seed flour

\section{Conclusion}

It was observed from this study, that there were variations in all the processing methods used and this shows that processing methods affected the compositional, functional and pasting characteristics of jackfruit seed flour.

Roasting prior to flour production gave the best results based on the following reasons. It made protein more available, increased the water absorption capacity with reduced oil absorption. In agreement with this finding Goswani et al (2010) reported an improvement in protein content from the raw $(6.73 \%)$ to the roasted $(7.32 \%)$ and fiber of raw seed $(1.6 \%)$ and $(3.38 \%)$ in the roasted jackfruit seed flour in the present study. Roasting also positively affected amylose content which is an important factor with regard to the end use properties of the product. It also had high peak viscosity, trough, break down, final viscosity and short pasting time. The higher water absorption capacity of the roasted sample indicated an important processing parameter that has implications for viscosity. In addition to water absorption in relation to its protein content and good viscosity properties are all important in bulking and consistency of the product and will find application in baking and confectionaries.

\section{References}

[1] Burkill, H.M. (1997): The useful plants of West Tropical Africa. vol. 4, $2^{\text {nd }}$ edition, Royal Botanic gardens, Kew, pp 160-161

[2] Berry, S.K., and Kalra, C.L. (1988): Chemistry and Technology of jackfruit (Artocarpus heterophyllus). A review. Indianfood packer; 42, 62-76.

[3] Ahmed, K. M. Malek, K. Jahan and K Salamatullah, (1986): Nutritive value of food stuff $3^{\text {rd }}$ edition, institute of nutrition and food science, University of Dhaka, Banglesdesh pp 1617.

[4] Goswani C, Hossain M.A, Mortuza M.G and Islam R. (2010): Physicochemical parameters of Jackfruit seeds in different growing Areas. Int J. Bio Res 2 (10) 01- 05

[5] Rajarajeshwari, H. and Jamuna, P. (1999): Jackfruit seeds; composition, functionality and use in product formulation. The int. Journal of Nutrition \& Dietetics, 36: 312-319.

[6] Kulkani, K.D, Kulkani, D.N and Ingle, U.M (1991): Sorghum malt-based weaning formulations preparation, functional properties and nutritive values". Food and Nutrition Bulletin 13(4): 322-327. 
[7] Takashi, S., and Sieb, P.A. (1988): Paste and gell properties of prime corn and wheat starches with and without native lipids. Cereal Chemistry, 65, 474-475.

[8] Sosulski, F.W., (1962): The centrifuge method for determining fat absorption in hard red spring wheat. Cereal Chemistry, 39: 344-346.

[9] Narayana, K and Narasinga, Rao Ms (1984): Effect of partial proteolysis on the functional properties of winged pea (Psophocapus tetragonolobus) flour. Journal of Food Science, 49:944-947.

[10] Coffman, C.W. and V.V. Garcia, (1977): "Functional properties and amino acid content of protein isolate from mungbean”. Journal of Food Technology, 12: 473.

[11] Francis F. (1998): Colour analysis in: food S.S. Nielsen ed Aspen Publishers, Gaithersburg, USA pp 559-612.

[12] Association of Official Analytical Chemist (AOAC) (1980). Official Methods of Analysis. Washington D.C.

[13] Mayanard, A.J. (1970). Methods in Food Analysis, Academic Press, New York, P. 176.

[14] Raghuramulu, N., Nair, M.K. and Kalyansundaram, S. (1983): In: A Manual of Laboratory Techniques, NIN, ICMR, Hyderabad, India.

[15] Dubois, M., Gilles, K.A. Hamilton, J.k., Reberts, P.A and Smith, F. (1956) "Colorimetric method for determination of sugar and related substances", Anal chem. 28:350-356. As reported by Eke (2006) $\mathrm{PhD}$ Thesis.

[16] Eke-Ejiofor J. and Kin-Kabari D.B. (2010): Chemical Properties of Sweet and Irish Potato Chips. Nigerian Food Journal, Vol 28, No. 22010 pages 47-52

[17] Williams, P.C. Kuzina, F.D. and Hlynka I.A (1970) A rapid calorimetric procedure for estimating the amylose content of starches and starch. Cereal Chemistry, 47 (4) 411-413.

[18] Duncan P, B (1955). New Multiple Range and Multiple Ftests Biometrics, 11:1-42.

[19] Odoemelam, S.A. (2005): "Functional properties of raw and heat processed jackfruit seeds flour". Pakistan Journal of Nutrition, 4 (6): 366-370.

[20] Talyathan V., Tananuwong, K., Songjinda, P. and Jarboon, W. (2002): Some physico-chemical properties of jackfruit (Artocarpus heterophyllus) seed flour and starch. Science Asia 28:37-41

[21] Niba, L.L., Bokanga, M.M., Jackson, F.L., Schllmme, D.S. and Li, B.W. (2001): Physiochemical properties and starch granular characteristics of flour from various Manihot esculents (cassava) genotypes. Journal of Food Science, $67(5)$.

[22] Ocloo, F.C.K, Bansa, D. Boatin, R. Adom, T. Agbemavor, W.S. (2010): Physicochemical, functional and pasting characteristics of flour produced from jackfruits (Artocarpus heterophyllus) seeds. Agric and Biology Journal of North America, 1(5): 903-908.

[23] Daramola, B. and Osanyinlusi, S.A. (2006): Investigation on modification of cassava starch using active components of giner root (Zingiber officinale Roscoe). African journal of Biotechnology vol. 5 (10), Pp 917-920.
[24] Rickard, J.E, Blanshard, J.M.V., Asaoka, M. (1992): Effects of cultivar and growth season on the gelatinization properties of cassava (Manihot esculenta) starch. J. Science Food and Agriculture, (59) 53-58.

[25] Hari, P.K., Gargs, S and Garg, S. (1989): Gelatinization of Starch and modified starch. Starke 41(3): 88-91.

[26] Adebowale, A.A. (2002): Effect of texture modifiers on the physicochemical and sensory properties of dried fufu, unpublished M.Sc Thesis University of Agriculture Abeokuta Nigeria Pg 28-49.

[27] Chowdbury, Roy. A, Blaattacharyya, K.A and Chattpadhyay, P. (2012): Study on the Functional properties of raw and blended jackfruit seed flour (a non conventional source) for food application. Indian Journal of Natural Products and Resurces. Vol 3(3), pp 347-353/

[28] Enwere, N.J. and Ngoddy, P.O. (1986): Effect of heat treatment on selected functional of cowpea flour. Journal of Tropical Science, (26) 223-232.

[29] Amornrat, M and Karmontip, S. (2004): "Physicochemical properties of flour and starch from jackfruit seed (Artocarpus heterophyllus lam) compared with modified starches". International Journal of Food Science and Technology, 39, 271-276.

[30] Morton, J. (1987), fruits of warm climates. Miami, Florida, 58-64.

[31] Kumar Sanjeev, Singh, A.B, Abidi, A.B., Upadhyay; R.G. and Singh, Ajay, (1988): Proximate composition of jackfruit seeds. Journal of Food Science and Tech., 25(5): 308-309.

[32] Bobbio, F.O., EL-Dash A.A., Bobbio, P.A. and Rodrigues, L.R., (1978): Isolation and characterization of the physicochemical properties of the starch of jackfruit seeds. Cereal chemistry, 55(4): 505-511

[33] Singh, A. Kumar, S. and Singh, I.S. (1991): Functional Properties of Jackfruit seed flour. Lebensm-Will U Technology, 24:373-374.

[34] Oshodi, A.A., Ogungbele, H.N., Oladimeji, M.O. (1999): Chemical Composition, nutritionally valuable minerals and functional properties of Benniseed, pearl mullet and quinoa flours. Intl Journal of Food Science and Nutrition, 50: 325331.

[35] Okpala, L.C. and Mammah, E.N. (2001): Functional properties of raw and processes pigeon pea (Cajanus cajan) flour”. Int. J. of Food Science and Nutrition, 52:343-346.

[36] Akubor, P.I., Badifu, G.I.O (2004): Chemical composition, functional properties and baking potential of african breadfruit kernel and wheat flour blends. Int. Journal of Food Sci. Tech. 39:223-229

[37] Siti, S.M and Noor, A.A.A. (2003): Effects of different levels of jackfruit seed flours on the quality characteristics of reduced fat muffins. Food Sci and Tech. Division, school of industrial technology, Universiti Sains Malaysia, 11800 Minden, Palau Pinang.

[38] Raja, K.C. M., and Ramakrishma S.U. (1990): Compositional and pasting characteristics of plain-dried and par-boiled cassava (Manihot esculenta crantz). Food Chemistry 38:79-88. 
[39] Sievert, D and Lausanne, J.H. (1993): Determination of Amylose by Differential scanning calorimetry. starch/starke 45 (4): 136-139

[40] Swinkels, J.J. M (1985): Composition and properties of commercial native starches. starch/starke, 37(1): 1-5.
[41] Moorthy S.N., Rickard J and J.M.R. Blanshard,(1996): Influence of gelatinization of cassava starch and flour on the textural properties of some food products. Progress in research and development, D. Dufor, G.M. O'brien and Rupert Best (eds). Montpeller, France 1996, 150-155. 